\title{
Role of sexual reproduction in the aggressiveness of Didymella rabiei affecting chickpea
}

\author{
Basem Attar ${ }^{1}$, Seid Ahmed ${ }^{2}$, Mukaddes Kayim ${ }^{3}$, Elia Choueiri ${ }^{4}$, Hend A. Ghannam ${ }^{5}$ and Aladdin Hamwieh ${ }^{6}$
}

(1) International Center for Agricultural Research in The Dry Areas (ICARDA), Terbol Station, Beqa'a valley, Zahle, Lebanon, email: basematt@ hotmail.com; (2) ICARDA, Rabat, Morocco, email: s.a.kemal@cgiar.org; (3) Department of Plant Protection, Faculty of Agriculture, University of Çukurova, Balcali 01330 Adana, Turkey; (4) Department of Plant Protection, Lebanese Agricultural Research Institute, Tal Amara, Zahlé, Lebanon; (5) Department of Food Legumes Research, Field Crop Research Institute, Cairo, Egypt; (6) ICARDA, Cairo, Egypt.

\begin{abstract}
Attar, B., S. Ahmed, M. Kayim, E. Choueiri, H.A. Ghannam, A. Hamwieh. 2020. Role of sexual reproduction in the aggressiveness of Didymella rabiei affecting chickpea. Arab Journal of Plant Protection, 38(1): 17-24.

Chickpea production is affected by Ascochyta blight disease in many countries and popular cultivars are put out of production due to the evolution of highly aggressive pathogen population. Sexual reproduction is believed to play an important role in the evolution of aggressive population in Didymella rabiei. Three crosses were made using four parental isolates (AR01 as MAT1-2 and AR02, AR03 and AR04 as MAT1-1) with varying levels of aggressiveness collected from Syria. Twenty randomly selected progenies per cross together with their respective parents were tested on susceptible (ILC-263) and resistant (ICC-12004) chickpea genotypes for their aggressiveness. Moreover, the mating type frequency was determined using multiplex Mating type markers. Latent period and disease severity were used to measure isolate aggressiveness in the progenies. The mean latent period ranged from 6-12 days in all progenies. The progenies showed significant differences on their aggressiveness in the three crosses. High level of aggressiveness of the progenies was generated from AR01 by AR04 crosses. The frequency of the two mating types was almost equal in all crosses. Our findings showed that sexual reproduction can create progenies that can adapt to resistant cultivars and could affect the effectiveness of commonly used fungicides to manage Ascochyta blight.

Keywords: Chickpea, Didymella rabiei, mating type, progenies.
\end{abstract}

\section{Introduction}

Chickpea (Cicer arietinum L.) is a major cool-season food legume crop in many parts of the world. The crop is produced for local consumption and export markets as well as in rotation to improve soil fertility benefiting succeeding cereal crops.

Chickpea (Desi and Kabuli types) is mainly planted in spring but in some countries like Syria winter planting is adopted where seed yield can be increased from 18-32\% over traditional spring production (Mazid et al., 2013). Chickpea production is affected by many diseases, insect pests, viruses and parasitic nematodes in many countries (Li et al., 2015).

Ascochyta blight (Didymella rabiei Kovatsch.) is the major biotic factor contributing for low yield and quality gaps in chickpea in many countries (Pande et al., 2005). Disease epidemics can be initiated from infected seeds, infected debris, and air borne ascospores produced from the teleomorph (Shtienberg et al., 2000). The anamorph (Ascochyta rabiei (Pass.) Lab.) is characterized by the presence of dark brown, spherical to pear-shaped pycnidia containing conidia on the aerial parts of chickpea plants. The teleomorph (D. rabiei) is characterized by dark brown to black pseudothecia on the overwintering chickpea debris (Kanouni et al., 2011).

The existence of two mating types of $D$. rabiei was reported in Syria, Canada, Turkey, Iran, Tunisia, Spain, and USA (Ali et al., 2012; Armstrong et al., 2001; Atik et al., 2011; Azizpour \& Rouhrazi, 2017; Bayraktar et al., 2007; Kaiser \& Küsmenoglu, 1997; Navas-Cortes et al., 1998;
Peever et al., 2004; Rhaiem et al., 2007). In most countries, Mating Type 1 is predominating in the pathogen populations. Breeding for host plant resistance and integrated disease management are considered as effective strategies to combat Ascochyta blight in many countries (Gan et al., 2006; Sharma \& Ghosh, 2016). The mode of Ascochyta blight resistance in chickpea is reported to be controlled by major (Labdi et al., 2013) and minor genes (Muehlbauer \& Chen, 2007; Rubiales \& Fondevilla, 2012; Sharma \& Ghosh, 2016). The most popular cultivar ILC- 3279 in west Asia released for winter sowing showed partial resistance to $D$. rabiei populations in Syria (Singh \& Reddy, 1993). Ascochyta blight resistant chickpea cultivars are reported to lose their resistance in some countries due to appearance of highly virulent/aggressive races of $D$. rabiei populations (Atik et al., 2013; Chen et al., 2004; Imtiaz et al., 2011; Mehmood et al., 2017; Reddy \& Kabbabeh, 1985; Vail \& Banniza, 2008).

Limited studies have been made to determine the driving forces leading to the development of new virulent/ aggressive Ascochyta populations affecting cool-season food legumes. Studies on the inheritance of virulence on some Ascochyta spp. affecting food legumes showed that sexual reproduction could contribute in the generation of more aggressive progenies that could threaten resistant cultivars (Ahmed \& Morrall, 1998; Beata \& Pang, 2003; Peever et al., 2012). The objective of this study was to determine if sexual reproduction plays a role in creating aggressive in $D$. rabiei population progenies by using progenies obtained from crosses between fungal isolates

http://dx.doi.org/10.22268/AJPP-038.1.017024

(C) 2020 Arab Society for Plant Protection الجمعية العربية لوقاية النبات 
with varying level of aggressiveness and comparing the effect of these progenies on chickpea genotypes with varying levels of Ascochyta blight resistance.

\section{Materials and Methods}

\section{Crossing}

Four isolates of D. rabiei with varying levels of aggressiveness (AR01, AR02, AR03 and AR04) collected from Syria were used in the crossing (Imtiaz et al., 2011; Udupa et al., 1998). The isolates were used to screen kabuli chickpea breeding lines and accessions for Ascochyta blight resistance at the International Center for Agricultural Research in the Dry Areas (ICARDA). The parent isolates were classified as MAT1-1 (AR02, AR03 and AR04) and MAT1-2 (AR01) by Atik et al (2011). The parents were grown on chickpea dextrose agar (CDA: $4 \%$ chickpea flour; $2 \%$ dextrose and $2 \%$ agar in one liter of distilled water) for one week inside a culture room at $21-23^{\circ} \mathrm{C}$ under $16 / 8 \mathrm{~h}$ light and darkness. Three crosses namely Cross-1 (AR01 X AR02); Cross-2 (AR01 X AR03) and Cross-3 (AR01 X AR04) were made using sterilized chickpea stem inoculation technique (Trapero-Casas \& Kaiser, 1992).

Sterilized stem pieces from healthy chickpea plants were inoculated with $7 \times 10^{5}$ spores. $\mathrm{ml}^{-1}$ in suspension of the crosses and parent progenies. Stem pieces (6-8 cm long) were soaked in spore suspensions for $1 \mathrm{~h}$, drained and placed in glass Petri dishes containing 10 filter papers moistened with sterile distilled water. After 7-9 weeks under darkness and $10^{\circ} \mathrm{C}$ inside incubator, small parts of stem pieces were checked microscopically for the presence of pseudothecia, the stem pieces were then air-dried at $21-23^{\circ} \mathrm{C}$ in a Laminar Flow hood and ascospores were discharged from inoculated stem pieces by placing pieces of stem $(2.5 \mathrm{~cm}$ long) on a water agar block placed on the inner surface of a Petri dish which was inverted over a bottom dish that contained water agar. Ascospores discharged downwards onto the surface of the plate were incubated at 21 to $23^{\circ} \mathrm{C}$ for $24 \mathrm{~h}$ to observe their germination. Twenty randomly selected single ascospores from each cross were transferred to CDA and incubated for one week at $22-23^{\circ} \mathrm{C}$ under similar light regime mentioned earlier. Each progeny was kept inside $1.5 \mathrm{ml}$ Eppendorf tube containing sterilized distilled water at $-20^{\circ} \mathrm{C}$ until further use.

\section{Seedling inoculation}

Seeds of two chickpea genotypes, namely, ILC-263 (Kabuli) susceptible to the four parent isolates and ICC-12004 (Desi) resistant to AR01, AR02 and AR03 but susceptible to AR04 (Imtiaz et al., 2011; Udupa et al., 1998) were surface sterilized using $2 \% \mathrm{NaOCl}$, dried on filter paper under laminar flow and planted in plastic pots $(12 \mathrm{~cm}$ diameter) filled with sterilized soil mixture. Four seeds/pot of each chickpea genotype were planted and kept in the glasshouse $\left(18-20^{\circ} \mathrm{C}, 16 / 8 \mathrm{~h}\right.$ photoperiod). The aggressiveness of progenies and parent isolates of each cross was separately tested on the two chickpea genotypes in randomized complete block design with three replications (one pot with four seedlings as one replication) in a glasshouse at the
Lebanese Agricultural Research Institute (LARI), Tal Amara, Lebanon in 2014.

At 4-6 leaf stages, chickpea seedlings were inoculated with spore suspension $\left(5 \times 10^{5} \mathrm{ml}^{-1}\right)$ of the $\mathrm{F}_{1}$ progenies and their respective parents until runoff using 0.25 liter hand sprayers. Inoculated seedlings were covered with polyethylene sheets for $72 \mathrm{~h}$ under glasshouse conditions at $18-20^{\circ} \mathrm{C}$, and after removing the cover, seedlings were kept under high humidity in the glasshouse (more than $85 \%$ ) maintained by using controlled mist irrigation system. Latent period (LP) was recorded as the interval (days) between inoculation and first appearance of pycnidia on infected leaves and/or stem of the seedlings. Disease severity was rated 15 days after inoculation using 1-9 rating scale where $1=$ healthy plant, no disease; 2 = lesions present, but small and inconspicuous; $3=$ lesions easily seen, but plants are mostly green; $4=$ severe lesions clearly visible, stem infection is clear; $5=$ lesions girdle stems, most leaves show lesions; $6=$ plants collapse, tips die back; $7=$ plants dying, but at least green leaves present; $8=$ nearly all plants dead but still with a green stem; and 9= dead plants (Chen et al., 2004).

\section{Mating type of $D$. rabiei progenies}

The mating type frequency of 57 progenies from the three crosses was assessed using MAT specific markers (Barve et al., 2003). Four discs (5 mm diameter) of each progeny and parent progenies were inoculated into $250 \mathrm{ml}$ flasks containing $50 \mathrm{ml}$ of potato dextrose broth medium. After 46 days of incubation on rotary shaker $\left(50 \mathrm{rpm}\right.$ and $\left.20^{\circ} \mathrm{C}\right)$, mycelia were harvested from the flasks by vacuum filtration method using two layers of sterilized cheese cloth, lyophilized for five days and stored at $-30^{\circ} \mathrm{C}$. Approximately $50 \mathrm{mg}$ of the lyophilized mycelium was transferred to microfuge tubes and re-lyophilized for an additional day. Mycelium of each isolate was grinded to a fine powder by liquid nitrogen using ceramic mortars (Chongo et al., 2004). Total fungal genomic DNA was extracted from all progenies and parental progenies using the hexadecyltrimethyl -ammonium bromide (CTAB) extraction buffer (1.4 M NaCl, 0.1 M Tris-HCl pH 8.0, 20mM EDTA, $0.2 \% \beta$-mercaptoethanol) using the method of Atik et al. (2011). The powdered lyophilized mycelia were dissolved in $1.2 \mathrm{ml}$ of CTAB and transferred to $2 \mathrm{ml}$ Eppendorf tubes and placed in water bath at $65^{\circ} \mathrm{C}$ for $60 \mathrm{~min}$. After removing Eppendorf tubes from the water bath, $600 \mu 1$ of chloroformisoamyl alcohol $(24: 1 \mathrm{v} / \mathrm{v})$ were added and tubes were hand shaken gently for $15 \mathrm{~min}$ and centrifuged for $20 \mathrm{~min}$ at 13000 rpm. The upper part of the liquid was transferred to another Eppendorf tube and $700 \mu \mathrm{l}$ of cool isopropanol were added and shaken gently for 2 min then it was kept in the freezer for $10 \mathrm{~min}$, centrifuged for $15 \mathrm{~min}$ at $13000 \mathrm{rpm}$ and the supernatant was discarded. Finally, the DNA pellet was washed twice with $1 \mathrm{ml}$ of $70 \%$ ethanol, allowed to be air dried for 3 hours and dissolved in $1 \times$ TE buffer $(10 \mathrm{mM}$ Tris $\mathrm{Cl}, \mathrm{PH} 8.0,1 \mathrm{mM}$ EDTA). The quantity and quality of the extracted DNA were assessed by running $1 \mu 1$ of the DNA on $1 \%$ of agarose gel, stained with ethidium bromide and photographed under UV illumination.

Mating types were determined using multiplex MATspecific PCR with three primers: MAT1-1 specific primer 
Sp21 (5'-ACAGTGAGCCTGCACAGTTC-3'), MAT1-2 specific primer Tail 5 (5'CGCTATTTTATCCAAGACACACC-3') and flanking region-specific primer Com1 (5'GCATGCCATATCGCCAGT-3') were combined in equal concentrations in a single multiplex PCR (Barve et al., 2003). Reactions were made up of $12 \mathrm{ng}$ DNA template, 400 $\mathrm{nM}$ of each primer (Tail5, Com1andSP21), $2.5 \mu 110 \times \mathrm{TAE}$ buffer, $1.5 \mathrm{mM} \mathrm{MgCl} 2,25 \mathrm{mM}$ dNTPs each, $1 \mathrm{U}$ Taq DNA polymerase (Invitrogen Life Technologies) and were adjusted to a volume of $25 \mu \mathrm{l}$ with sterile, double-deionized water. Amplifications were performed with a PTC-200 Peltier Thermal Cycler (MJ Research, Waltham, MA) with an initial denaturation step of $95^{\circ} \mathrm{C}$ for $3 \mathrm{~min}$ followed by 44 cycles of $95^{\circ} \mathrm{C}$, for $30 \mathrm{~s}, 60^{\circ} \mathrm{C}$ for $30 \mathrm{~s}$ and $72^{\circ} \mathrm{C}$ for $1 \mathrm{~min}$ for each cycle, with a final extension of $72^{\circ} \mathrm{C}$ for $5 \mathrm{~min}$. Amplified products were separated by electrophoresis on a $1.5 \%$ of agarose gel stained with ethidium bromide and photographed under UV illumination.

\section{Data analyses}

Latent period (LP) and disease severity (mean of four plants/pot) were analyzed using the residual (restricted) maximum likelihood (REML) method in linear mixed model (Garrett et al., 2004) using Genstate Software (16 $6^{\text {th }}$ edition). In the model, chickpea genotypes and pathogen progenies were assigned as fixed and replications as random factors. Least square differences were calculated using the standard errors of the differences.

\section{Results}

Pseudothecia were observed 7-9 weeks after incubation from all crosses. The frequency of the two mating types in the three crosses was almost equal (Table1). However, there were more progenies with MAT1-2 in the cross of AR01 X AR03 than the other two crosses (Figure 1).

Table 1. Segregation of MAT1-1, MAT1-2 in crossed progeny using MAT specific primers.

\begin{tabular}{lccc}
\hline Cross & MAT1-1 & MAT1-2 & Ratio \\
\hline AR01xAR02 & 10 & 10 & $10: 10$ \\
AR01xAR03 & 8 & 10 & $8: 10$ \\
AR01xAR04 & 11 & 8 & $11: 8$ \\
\hline
\end{tabular}

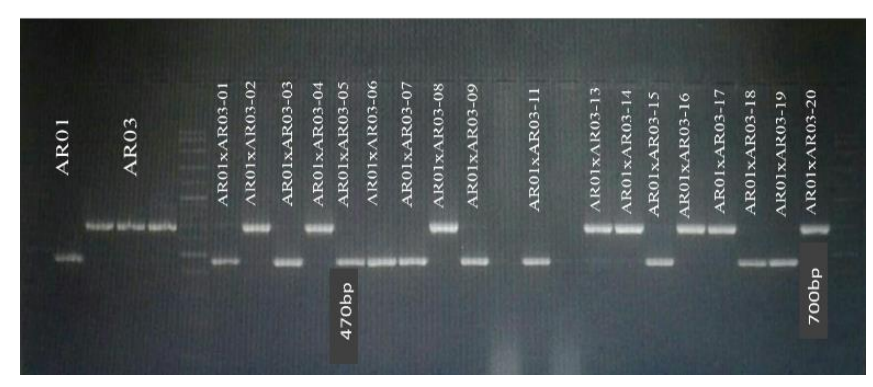

Figure 1. Multiplex polymerase chain reaction for MAT genes of 18 progenies and two parents from AR01 (MAT1$2=470 \mathrm{bp}$ ) X AR03 (MAT1-1=700bp) cross.
In the aggressiveness studies, all progenies of the three crosses and parent progenies caused infections on both chickpea genotypes. In Cross-1, significant differences were not observed among progenies for latent period (LP). The duration for the formation of pycnidia ranged from 7-12 days among progenies infecting the two chickpea genotypes. Six progenies (five on ICC-12004 and one on ILC-263) did not produce pycnidia under the prevailing environmental conditions in the glasshouse (Figure 2). Some progenies showed shorter LP than their parents on the two chickpea genotypes.

Significant differences $(\mathrm{P}<0.001)$ were observed among progenies on their aggressiveness on the two chickpea genotypes. Most progenies caused low mean disease severity ( $<4$ rating) on genotype ICC-12004 and 12 progenies caused higher disease severity on ILC-263 than AR01 parental progeny (Table 2). The mean severity ranged from 1.5 to 5.9 and the highest mean disease severity was caused by AR02.

Table 2. Aggressiveness of progenies of AR01 X AR02 cross as measured by disease severity on two chickpea genotypes.

\begin{tabular}{lccc}
\hline Progenies & \multicolumn{3}{c}{ Disease severity } \\
\cline { 2 - 4 } and parents & ICC-12004 & ILC-263 & Mean \\
\hline AR01 & 2.2 & 3.9 & 3.0 \\
AR02 & 4.8 & 7.0 & 5.9 \\
AR01XAR02-01 & 2.2 & 4.5 & 3.3 \\
AR01XAR02-02 & 1.8 & 3.6 & 2.7 \\
AR01XAR02-03 & 1.8 & 2.0 & 1.9 \\
AR01XAR02-04 & 1.4 & 2.6 & 2.0 \\
AR01XAR02-05 & 2.5 & 5.0 & 3.8 \\
AR01XAR02-06 & 2.7 & 4.7 & 3.7 \\
AR01XAR02-07 & 1.4 & 1.6 & 1.5 \\
AR01XAR02-08 & 1.9 & 3.0 & 2.4 \\
AR01XAR02-09 & 1.8 & 2.3 & 2.1 \\
AR01XAR02-10 & 1.7 & 4.5 & 3.1 \\
AR01XAR02-11 & 2.8 & 4.9 & 3.9 \\
AR01XAR02-12 & 1.8 & 4.9 & 3.3 \\
AR01XAR02-13 & 3.0 & 5.9 & 4.4 \\
AR01XAR02-14 & 2.4 & 2.9 & 2.7 \\
AR01XAR02-15 & 1.9 & 6.4 & 4.2 \\
AR01XAR02-16 & 2.7 & 3.7 & 3.2 \\
AR01XAR02-17 & 2.8 & 5.2 & 4.0 \\
AR01XAR02-18 & 2.7 & 4.6 & 3.6 \\
AR01XAR02-19 & 2.6 & 4.5 & 3.5 \\
AR01XAR02-20 & 2.4 & 5.0 & 3.7 \\
Mean & 2.3 & 4.2 & \\
\hline Standard error of the difference for progenies $=0.628$ \\
LSD (0.01 df=21) for progenies= 2.831 X 0.63=1.78
\end{tabular}

In cross-2, significant differences $(\mathrm{P}<0.001)$ were observed among progenies for LP (Figure 3). The duration for the formation of pycnidia range was 7-12 days and all progenies showed long LP on genotype ICC-12004. Some progenies formed pycnidia in shorter duration than parent progenies. For disease severity, the interaction between chickpea genotypes and progenies for disease severity was significant $(\mathrm{P}<0.03)$. The mean disease severity ranged 
from 1.8 to 4 rating indicating low levels of progenies aggressiveness. All progenies caused low disease severity $(<$ 3 rating) on genotype ICC-12004 and four progenies caused $>5$ rating on genotype ILC-263 (Table 3 ).

In cross-3, all progenies produced pycnidia on both chickpea genotypes except one progeny did not produce pycnidia on genotype ICC-12004, and significant differences were observed among progenies for LP. The duration of pycnidia formation range was 6-12 days (Figure 4). The interaction between chickpea genotypes by progenies for disease severity was highly significant $(\mathrm{P}<0.001)$. The mean disease severity ranged from 3.5 to 6.3 rating and progenies showed low disease severity on ICC-12004 ( $<4$ rating) but high disease severity on ILC-263, and one progeny caused higher disease severity on ILC-263 than AR04 parental progeny (Table 4).

The correlations of LP and aggressiveness of progenies (as measured by disease severity) were negative and significant. The correlations ranged from medium (Cross-1, $\mathrm{r}=-0.3, \mathrm{P}<0.01$; Cross- $2, \mathrm{r}=-0.4 \mathrm{P}<0.001$ ) to high (Cross$3, \mathrm{r}=-0.04, \mathrm{P}<0.001)$.

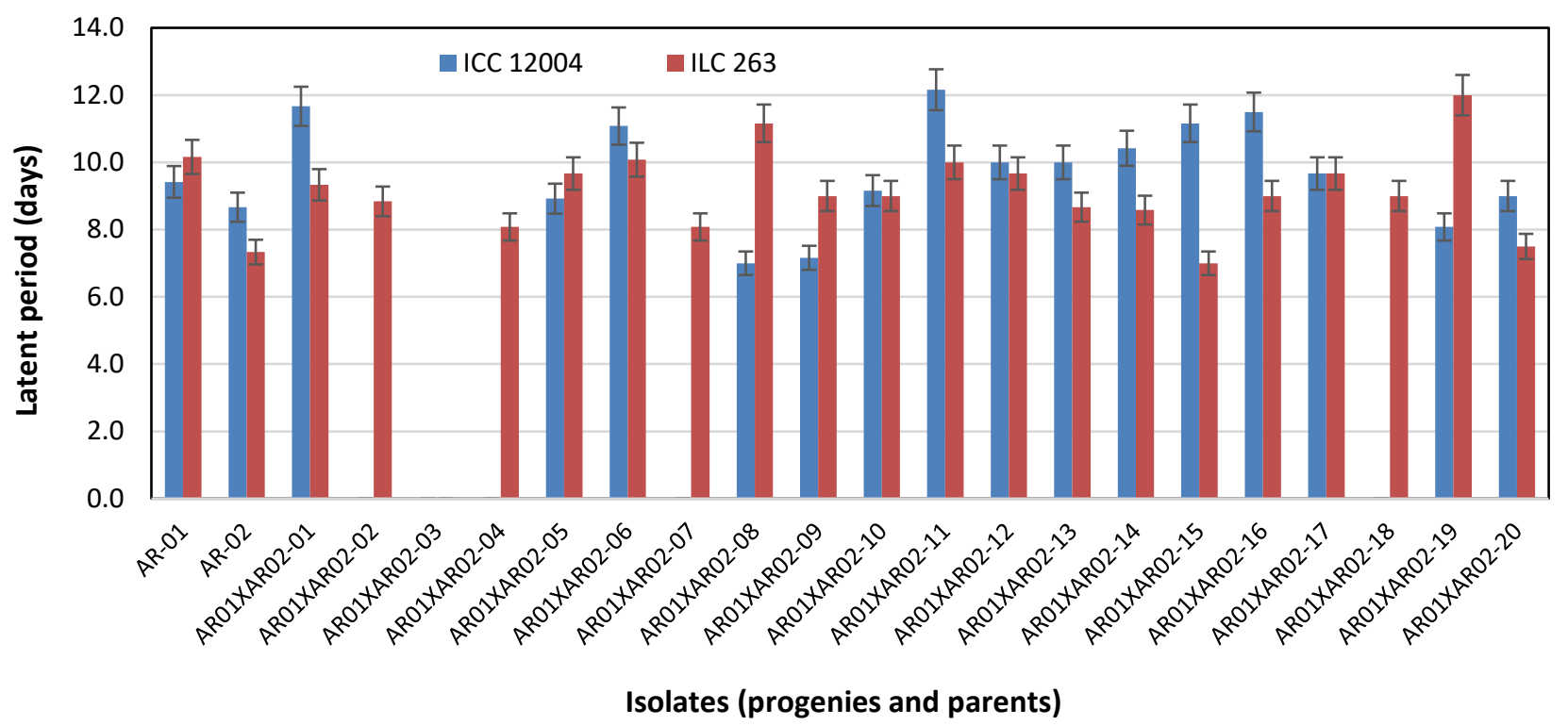

Figure 2. Duration of pycnidia formation by progenies (AR01 X AR02 cross) inoculated on two chickpea genotypes. Bars represent standard errors.

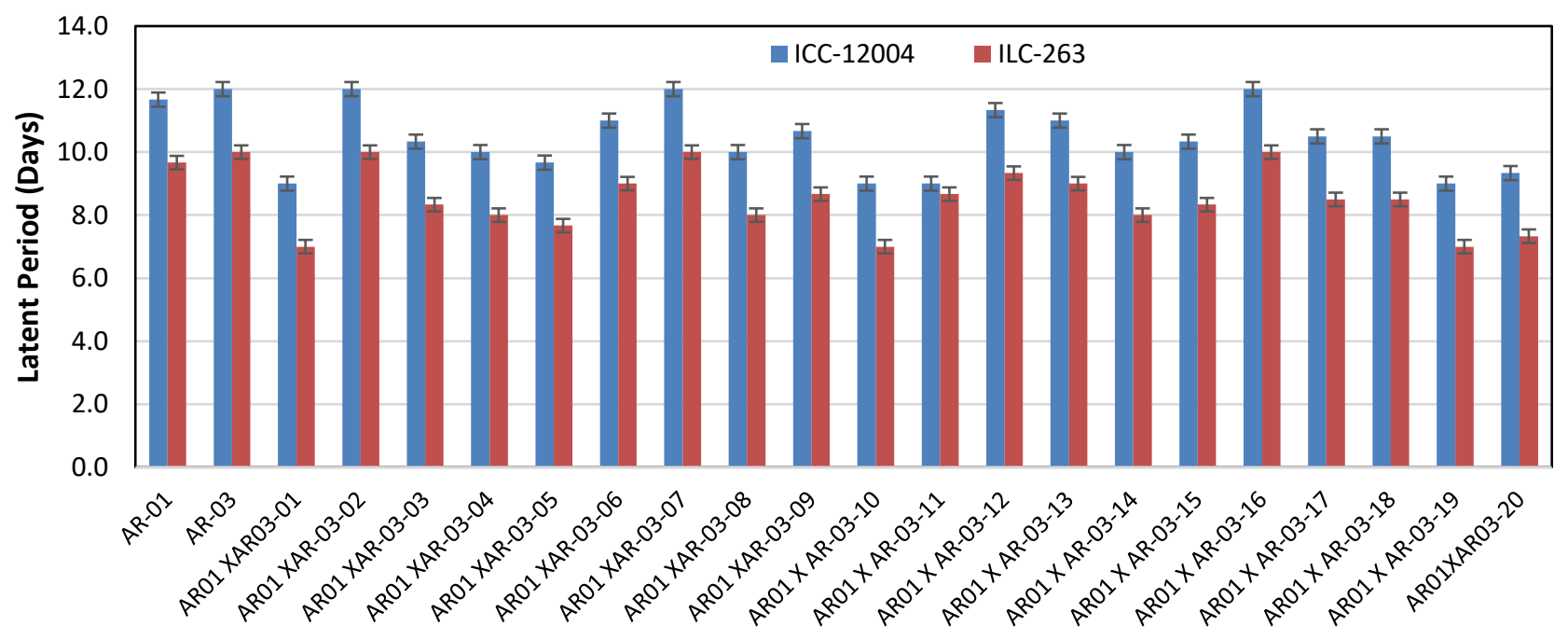

Isolates (progenies and parents)

Figure 3. Duration of pycnidia formation by progenies (AR01 X AR03 cross) inoculated on two chickpea genotypes. Bars represent standard errors. 


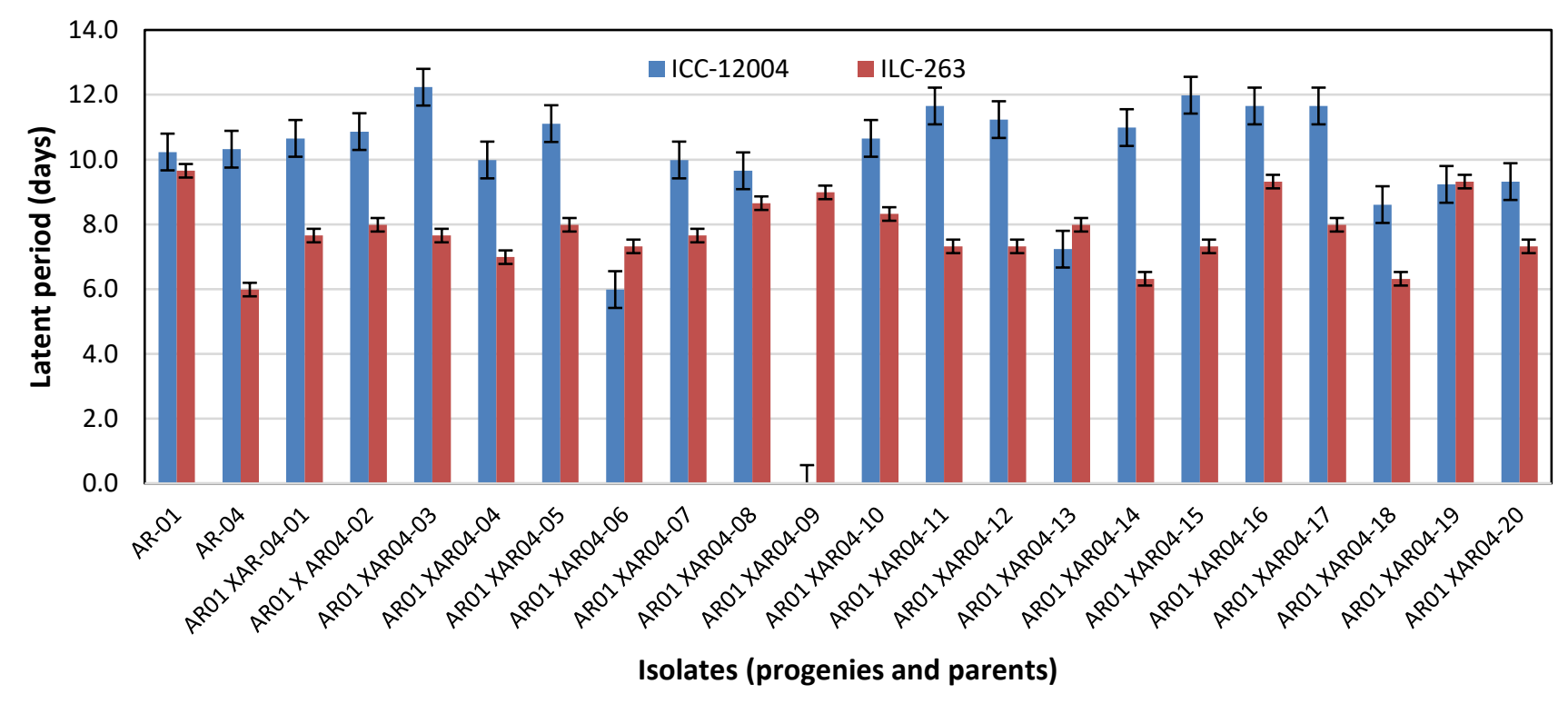

Figure 4. Duration of pycnidia formation by progenies (AR01 X AR04 cross) inoculated on two chickpea genotypes. Bars represent standard errors.

Table 3. Aggressiveness of progenies of AR01 X AR03 crosses as measured by disease severity on two chickpea genotypes.

\begin{tabular}{lccc}
\hline & \multicolumn{3}{c}{ Disease severity } \\
\cline { 2 - 4 } Progenies & ICC- & ILC- \\
and parents & $\mathbf{1 2 0 0 4}$ & $\mathbf{2 6 3}$ & Mean \\
\hline AR01 & 1.5 & 3.8 & 2.7 \\
AR03 & 1.6 & 4.0 & 3.1 \\
AR01 XAR03-01 & 1.6 & 2.6 & 2.1 \\
AR01 XAR03-02 & 1.8 & 4.6 & 2.3 \\
AR01 XAR03-03 & 1.7 & 5.1 & 3.2 \\
AR01 XAR03-04 & 1.4 & 3.9 & 2.7 \\
AR01 XAR03-05 & 2.1 & 5.8 & 4.0 \\
AR01 XAR03-06 & 2.1 & 2.5 & 2.3 \\
AR01 XAR03-07 & 1.9 & 5.3 & 3.6 \\
AR01 XAR03-08 & 1.2 & 2.4 & 1.8 \\
AR01 XAR03-09 & 1.8 & 4.0 & 2.9 \\
AR01 XAR03-10 & 1.5 & 2.8 & 2.2 \\
AR01 XAR03-11 & 1.6 & 3.3 & 2.5 \\
AR01 XAR03-12 & 1.3 & 3.3 & 2.3 \\
AR01 XAR03-13 & 2.4 & 4.9 & 3.6 \\
AR01 XAR03-14 & 1.8 & 5.2 & 3.5 \\
AR01 XAR03-15 & 1.4 & 3.6 & 2.5 \\
AR01 XAR03-16 & 2.0 & 3.8 & 2.9 \\
AR01 XAR03-17 & 1.5 & 2.9 & 2.2 \\
AR01 XAR03-18 & 2.1 & 3.9 & 3.0 \\
AR01 XAR03-19 & 1.8 & 3.7 & 2.8 \\
AR01 XAR03-20 & 1.7 & 3.8 & \\
Mean & 1.9 &
\end{tabular}

Standard error of differences for genotype by isolate interaction $=0.6392$

$\operatorname{LSD}(0.01 \mathrm{df}=21)$ for genotype $\mathrm{X}$ isolate interaction $=1.81$
Table 4. Aggressiveness of progenies of AR01 X AR04 crosses as measured by disease severity on two chickpea genotypes.

\begin{tabular}{lccc}
\hline Progenies & \multicolumn{3}{c}{ Disease severity } \\
\cline { 2 - 4 } and parents & ICC-12004 & ILC-263 & Mean \\
\hline AR01 & 4.8 & 5.6 & 4.3 \\
AR04 & 2.3 & 9.2 & 6.3 \\
AR01 XAR04-01 & 2.4 & 6.3 & 5.6 \\
AR01 X AR04-02 & 2.1 & 6.4 & 4.4 \\
AR01 XAR04-03 & 2.6 & 6.4 & 4.3 \\
AR01 XAR04-04 & 2.3 & 6.3 & 4.3 \\
AR01 XAR04-05 & 2.0 & 6.2 & 4.1 \\
AR01 XAR04-06 & 2.9 & 7.6 & 5.3 \\
AR01 XAR04-07 & 2.7 & 7.0 & 4.8 \\
AR01 XAR04-08 & 1.8 & 5.4 & 3.6 \\
AR01 XAR04-09 & 3.2 & 6.1 & 4.7 \\
AR01 XAR04-10 & 3.9 & 7.2 & 5.5 \\
AR01 XAR04-11 & 1.3 & 6.5 & 3.9 \\
AR01 XAR04-12 & 1.6 & 5.4 & 3.5 \\
AR01 XAR04-13 & 2.4 & 7.3 & 4.8 \\
AR01 XAR04-14 & 2.0 & 6.1 & 4.1 \\
AR01 XAR04-15 & 2.9 & 5.7 & 4.3 \\
AR01 XAR04-16 & 2.8 & 6.8 & 4.8 \\
AR01 XAR04-17 & 2.3 & 7.9 & 5.1 \\
AR01 XAR04-18 & 1.6 & 6.3 & 3.9 \\
AR01 XAR04-19 & 2.4 & 5.3 & 3.9 \\
AR01 XAR04-20 & 2.4 & 6.6 & \\
Mean & & & \\
\hline Standard error of differences (progenies) = 0.5198 & \\
LSD (0.01 df=21) for progenies= 1.47 & & \\
& & &
\end{tabular}




\section{Discussion}

Ascochyta blight is a high risk biotic yield limiting factor in many traditional and non-traditional chickpea producing countries (Chen et al., 2017; Rubiales \& Fondevilla, 2012; Viotti et al., 2012). Pathogens with sexual and asexual reproduction are considered as high risk (Heitman, 2015; McDonald \& Linde, 2002) and D. rabiei can be classified under this category since it can cause complete crop failure.

The major threat of resistant breeding is the evolution of virulent/aggressive $D$. rabiei populations in many countries. In our study the range in duration for the formation of pycnidia was similar to all progenies and parents in the three crosses. Some progenies did not produce pycnidia and the reasons are not known. Early formation of pycndia is critical to the pathogen fitness and also for creating epidemics under favorable conditions compared to progenies with long LP. Some progenies showed high aggressiveness on the susceptible genotype than the resistant ILC-12004. The formation of progenies with high virulence can be potential threat for resistant cultivars and also make fungicides less effective (Chang et al., 2007; Wise et al., 2008). Similar result showed that progenies of a weakly (progenies from Idaho, USA) and highly virulent (progenies northern Syria) D. rabiei progenies showed high disease severity on the susceptible cv. Spanish White than the moderately resistant cv. Dwelley (Peever et al., 2012).

The identification of the two mating types in almost equal frequency is similar to those reported from field populations of $D$. rabiei leading to random mating that can create high genetic diversity in the population. Published work showed that MAT1-1 is more dominant than MAT1-2 in D. rabiei populations (Ali et al., 2012; Atik et al., 2011; Bayraktar et al., 2007; Kaiser \& Küsmenoglu, 1997; Navas-
Cortes et al., 1998; Nourollahi et al., 2011; Rhaiem et al., 2007). However, MAT1-2 was dominant over MAT1-1 in North Dakota population (Ali et al., 2012). Some studies showed that extensive production of resistant chickpea (Leo et al., 2015; Mehmood et al., 2017; Peever et al., 2004) and lentil (Davidson et al., 2016) cultivars brought the appearances of aggressive pathogen populations Didymella spp affecting the two crops.

Conservation cropping where chickpea straw is left in the field will play a key role in generating new aggressive progenies through sexual reproduction in countries where the two mating types exist and environmental conditions are conducive for sexual reproduction. The progenies can affect resistant cultivars and make commonly used fungicides to manage Ascochyta blight less effective.

In conclusion, sexual reproduction through the mating of low by high aggressive parents in D. rabiei can create progenies with more aggressiveness and short LP that are critical to create disease epidemics that lead to high yield and quality losses in chickpea. Moreover, the response of the progenies to commonly used fungicides against Ascochyta blight and the role of mating type gene in pathogen isolate fitness should be studied.

\section{Acknowledgements}

The authors acknowledge the support provided by Michel Afram, Director General of LARI. The assistance of Ahmad Albitar, Fouad Jreijiri, Roula Al Amil and Joseph Kahwaji at LARI is also acknowledged. We thank the Institute of Natural and Applied Sciences of Çukurova University supporting the first Author during his stay at University. We also thank the support provided by Ali Endes, Faculty of Agriculture, Çukurova University.

\section{الملخص}

عidymella عار، باسم، سعيد أحمد، مقدس كايم، إيليا الثويري، هند غنام وعلاء حموية. 2020. تأثير التكاثر الجنسي على شراسة الفطر rabiei يؤثر مرض لفحة الأسكوكايتا سلبياً في إنتاجية محصول الحمص في العديد من البلدان، ومن الممكن للأصناف المقاومة المعتمدة أن تخرج من الاستخدام بسبب ظهور مجتمعات من هذا الممرض أكثر شراسة. من المحتمل أن يؤدي التكاثر الجنسي للفطر Didymella rabiei دوراً أساسياً في نشوء مجتمعات أكثر شراسة. تم

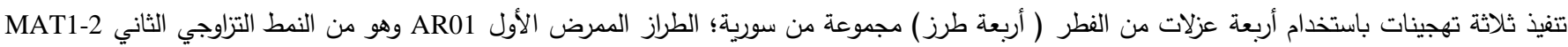

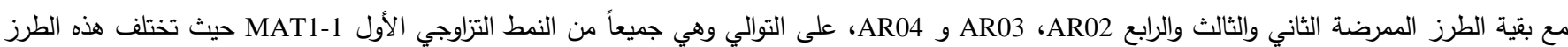

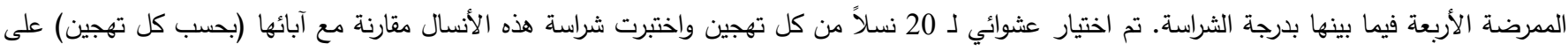
طرازي الحمص: ILC-263 الحساس للممرض و ICC-12004 المقاوم له، كما تم تحديد تردد الأنماط التزاوجية في الأنسال الناتجة باستخدام التفاعل التسلسلي للبوليميراز المتعدد. تم قياس شراسة الأنسال الناتجة عن التهجينات بوساطة فترة الكمون (Latent period) وشدة المرض. تراوحت فترة الكمون بين 6-12 يوماً في جميع الأنسال وكانت هناك فروق معنوية في شراسة الأنسال المتحصل عليها من التهجينات الثلاثة. تم الحصول على أعلى مستوى من الشراسة في الأنسال المتحصل عليها من

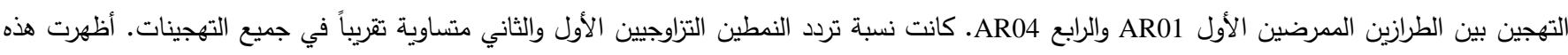

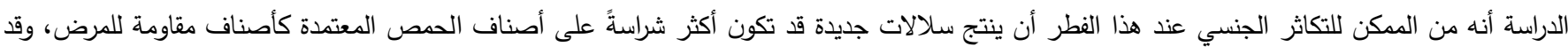

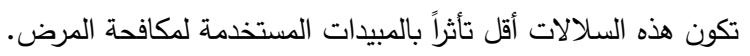
كلمات مفتاحية: Didymella rabiei، النمط التزاوجي، الأنسال، الحمص. 


\section{References}

Ahmed, S. and R.A.A. Morrall. 1998. Inheritance of virulence in Ascochyta fabae f. sp. lentis on lentil. LENS Newsletter, 25: 67-70.

Ali, H., S.S. Alam, R.N. Attanayake, M. Rahman and W. Chen. 2012. Population structure and mating type distribution of the chickpea blight pathogen Ascochyta rabiei from Pakistan and the United States. Journal of Plant Pathology, 94: 99-108.

Armstrong, C.L., G. Chongo, B.D. Gossen and L.J. Duczek. 2001. Mating type distribution and incidence of the teleomorph of Ascochyta rabiei (Didymella rabiei) in Canada. Canadian Journal of Plant Pathology, 23: 110-113. https://doi.org/10.1080/07060660109506917

Atik, O., M. Baum, A. El-Ahmed, S. Ahmed, M.M. Abang, M.M. Yabrak, S. Murad, S. Kabbabeh and A. Hamwieh. 2011. Chickpea ascochyta blight: disease status and pathogen mating type distribution in Syria. Journal of Phytopathology, 159: 443-449. https://doi.org/10.1111/j.1439-0434.2011.01788.x

Atik, O., S. Ahmed, M.M. Abang, M. Imtiaz, A. Hamwieh, M. Baum, A. El-Ahmad, S. Murad and M.M. Yabrak. 2013. Pathogenic and genetic diversity of Didymella rabiei affecting chickpea in Syria. Crop Protection, 46: 70-79. https://doi.org/10.1016/j.cropro.2012.12.012

Azizpour, N. and K. Rouhrazi. 2017. Assessment of genetic diversity of Iranian Ascochyta rabiei isolates using rep-PCR markers. Journal of Phytopathology, 165: 508-514. https://doi.org/10.1111/jph.12587

Barve, M.P., T. Arie, S. Salimath, F.J. Muehlabauer and T.L. Peever. 2003. Cloning and characterization of the mating type (MAT) locus from Ascochyta rabiei (teleomorph: Didymella rabiei) and MAT phylogeny of legume-associated Ascochyta spp. Fungal Genetics and Biology, 39: 151-167. https://doi.org/10.1016/s1087-1845(03)00015-x

Bayraktar, H., F.S. Dolar and S. Maden. 2007. Mating Type groups of Ascochyta rabiei (Teleomorph: Didymella rabiei) the causal agent of chickpea blight in central Anatolia. Turkish Journal of Agriculture and Forestry, 31: 41-46.

Beata, S. and E.C.K. Pang. 2003. Mating trials and genetic study of virulence in Ascochyta lentis to the lentil cultivar 'Northfield'. Australian Journal of Agricultural Research, 54: 453-460. https://doi.org/10.1071/ar02165

Chang, K.F., H.U. Ahmed, S.F. Hwang, B.D. Gossen, S.E. Strelkov, S.F. Blade and G.D. Turnbull. 2007. Sensitivity of field populations of Ascochyta rabiei to chlorothalonil, mancozeb, and pyraclostrobin fungicides, and effects of strobilurin fungicides on the progress of ascochyta blight of chickpea. Canadian Journal of Plant Science, 87: 937-944.

https://doi.org/10.4141/cjps07019

Chen, W., C.J. Coyne, T.L. Peever and F.J. Muehlbauer. 2004. Characterization of chickpea differentials for pathogenicity assay of ascochyta blight and identification of chickpea accessions resistant to Didymella rabiei. Plant Pathology, 53: 759-769.

https://doi.org/10.1111/j.1365-3059.2004.01103.x

Chen, X., J. Ge, D. Ma, L. Ma, W. Liu and S. Qiang. 2017. Characterization and identification of an Epidemic Strain of Ascochyta rabiei on Chickpeas in Northwest China. Journal of Phytopathology, 165: 355-360. https://doi.org/10.1111/jph.12568

Chongo, G., B.D. Gossen, L. Buchwaldt, T. Adhikari and S.R. Rimmer. 2004. Genetic diversity of Ascochyta rabiei in Canada. Plant Disease, 88: 4-10.

Davidson, J., G. Smetham, M.H. Russ, L. McMurray, M. Rodda, M. Krysinska-Kaczmarek and R. Ford. 2016. Changes in aggressiveness of the Ascochyta lentis population in southern Australia. Frontiers in Plant Science, 7:393.

https://doi.org/10.3389/fpls.2016.00393

Gan, Y.T., K.H.M. Siddique, W.J. MacLeod and P. Jayakumar. 2006. Management options for minimizing the damage by ascochyta blight (Ascochyta rabiei) in chickpea (Cicer arietinum L.). Field Crops Research, 97: 121-134. https://doi.org/10.1016/j.fcr.2005.10.002

Garrett, K.A., L.V. Madden, G. Hughes and W.F. Pfender. 2004. New applications of statistical tools in plant pathology. Phytopathology, 94: 999-1003. https://doi.org/10.1094/phyto.2004.94.9.999

Heitman, J. 2015. Evolution of sexual reproduction: A view from the fungal kingdom supports an evolutionary epoch with sex before sexes. Fungal Biology Reviews, 29: $108-117$. https://doi.org/10.1016/j.fbr.2015.08.002

Imtiaz, M., M. Abang, R.S. Malhotra, S. Ahmed, B. Bayaa, S.M. Udupa and M. Baum. 2011. Pathotype IV, a new and highly virulent pathotype of Didymella rabiei, causing Ascochyta Blight in chickpea in Syria. Plant Disease, 95: 1192. https://doi.org/10.1094/pdis-04-11-0333

Kaiser, W.J. and I. Küsmenoglu. 1997. Distribution of mating types and the teleomorph of Ascochyta rabiei on chickpea in Turkey. Plant Disease, 81: 1284-1287. https://doi.org/10.1094/pdis.1997.81.11.1284

Kanouni, H., A. Taleei and M. Okhovat. 2011. Ascochyta blight (Ascochyta rabiei (Pass.) Lab.) of chickpea (Cicer arietinum L.): Breeding strategies for resistance. International Journal of Plant Breeding and Genetics, 5:1-22. https://doi.org/10.3923/ijpbg.2011.1.22

Labdi, M., R.S. Malhotra, I.E. Benzohra and M. Imtiaz. 2013. Inheritance of resistance to Ascochyta rabiei in 15 chickpea germplasm accessions. Plant Breeding, 132: 197-199. https://doi.org/10.1111/pbr.12038

Leo, A.E., R. Ford and C.C. Linde. 2015. Genetic homogeneity of a recently introduced pathogen of chickpea, Ascochyta rabiei, to Australia. Biological Invasions, 17: 609-623. https://doi.org/10.1007/s10530-014-0752-8 
Li, H., M. Rodda, M. Gnanasambandam, M. Aftab, R. Redden, K. Hobson, G. Rosewarne, M. Materne, S. Kaur and A.T. Slater. 2015. Breeding for biotic stress resistance in chickpea: progress and prospects. Euphytica, 204: 257-288. https://doi.org/10.1007/s10681-015-1462-8

Mazid, A., K. Shideed, M. El-abdullah and G. Zyadeh. 2013. Impacts of crop improvement research on farmers' livelihoods: the case of winter-sown chickpea in Syria. Experimental Agriculture, 49: 336-351. https://doi.org/10.1017/s0014479712001342

McDonald, B.A. and C. Linde. 2002. Pathogen population genetics, evolutionary potential, and durable resistance. Annual Review of Phytopathology, 40: 349-379.

https://doi.org/10.1146/annurev.phyto.40.120501.101 443

Mehmood, Y., P. Sambasivam, S. Kaur, J. Davidson, A.E. Leo, K. Hobson, C.C. Linde, K. Moore, J. Brownlie and R. Ford. 2017. Evidence and consequence of a highly adapted clonal haplotype within the Australian Ascochyta rabiei population. Frontiers in Plant Science, 8: 1029. https://doi.org/10.3389/fpls.2017.01029

Muehlbauer, F.J. and W. Chen. 2007. Resistance to ascochyta blights of cool season food legumes. European Journal of Plant Pathology, 119: 135-141. https://doi.org/10.1007/s10658-007-9180-2

Navas-Cortes, J.A., E. Perez-Artes, R.M. Jimenez-Diaz, A. Lobell, B.W. Brainbridge and J.B. Heale. 1998. Mating type, pathotype, RAPDs analysis in Didymella rabiei, the agent of Ascochyta blight of chickpea. Phytoparasitica, 26: 199-212. https://doi.org/10.1007/bf02981435

Nourollahi, K., M. Javannikkhah, M. Naghavi, J. Lichtenzveig, S.M. Okhovat, R.P. Oliver and S.R. Ellwood. 2011. Genetic diversity and population structure of Ascochyta rabiei from the western Iranian Ilam and Kermanshah provinces using MAT and SSR markers. Mycological Progress, 10: 127. https://doi.org/10.1007/s11557-010-0689-y

Pande, S., K.H.M. Siddique, G.K. Kishore, B. Bayaa, P.M. Guar, C.L.L. Gowda, T.W. Bretag and G.H. Crouch. 2005. Ascochyta blight of chickpea (Cicer arietinum $\mathrm{L}$.): a review of biology, pathogenicity, and disease management. Australian Journal of Agricultural Research, 56: 317-332.

https://doi.org/10.1071/ar04143

Peever, T.L., S.S. Salimath, G. Su, W.J. Kaiser and F.J. Muehlbauer. 2004. Historical and contemporary multilocus population structure of Ascochyta rabiei (teleomorph: Didymella rabiei) in the Pacific Northwest of the United States. Molecular Ecology, 13: 291-309.

https://doi.org/10.1046/j.1365-294x.2003.02059.x
Peever, T.L., W. Chen, Z. Abdo and W.J. Kaiser. 2012. Genetics of virulence in Ascochyta rabiei. Plant Pathology, 61: 754-760. https://doi.org/10.1111/j.1365-3059.2011.02566.x

Reddy, M.V. and S. Kabbabeh. 1985. Pathogenic variability in Ascochyta rabiei (Pass.) Lab. in Syria and Lebanon. Phytopathologia Mediterranea, 24: 265-266.

Rhaiem, A., M. Chérif, P.S. Dyer and T.L. Peever. 2007. Distribution of mating types and genetic diversity of Ascochyta rabiei populations in Tunisia revealed by mating-type specific PCR and random amplified polymorphic DNA (RAPD) markers. Journal of phytopathology, 155: 596-605. https://doi.org/10.1111/j.1439-0434.2007.01285.x

Rubiales, D. and S. Fondevilla. 2012. Future prospects for ascochyta blight resistance breeding in cool season food legumes. Frontiers in Plant Science, 3: 27. https://doi.org/10.3389/fpls.2012.00027

Sharma, M. and R. Ghosh. 2016. An update on genetic resistance of chickpea to ascochyta blight. Agronomy, 6: 18. https://doi.org/10.3390/agronomy6010018

Shtienberg, D., H. Vintal, S. Brener and B. Retig. 2000. Rational management of Didymella rabiei in chickpea by integration of genotype resistance and post infection application of fungicides. Phytopathology, 90: 834842. https://doi.org/10.1094/phyto.2000.90.8.834

Singh, K.B. and M.V. Reddy. 1993. Resistance to six races of Ascochyta rabiei in the world germplasm collection of chickpea. Crop Science, 33: 186-189. https://doi.org/10.2135/cropsci1993.0011183x003300 $010033 \mathrm{x}$

Trapero-Casas, A. and W.J. Kaiser. 1992. Development of Didymella rabiei, The teleomorph of Ascochyta rabiei, on chickpea straw. Phytopathology, 82: 12611266. https://doi.org/10.1094/phyto-82-1261

Udupa, S., M.F. Weigand, M.C. Saxena and G. Kahl. 1998. Genotyping with RAPD and microsatellite markers resolves pathotype diversity in the Ascochyta blight pathogen in chickpea. Theoretical and Applied Genetics, 97: 299-307. https://doi.org/10.1007/s001220050899

Vail, S. and S. Banniza. 2008. Structure and pathogenic variability in Ascochyta rabiei populations on chickpea in the Canadian Prairies. Plant Pathology, 57: 665-673. https://doi.org/10.1111/j.1365-3059.2008.01837.x

Viotti, G., M.A. Carmona, M. Scandiani, A.N. Formento and A. Luque. 2012. First report of Ascochyta rabiei causing ascochyta blight of chickpea in Argentina. Plant Disease, 96: 1375. https://doi.org/10.1094/pdis-02-12-0153-pdn

Wise, K.A., C.A. Bradley, J.S. Pasche, N.C. Gudmestad, F.M. Dugan and W. Chen. 2008. Baseline sensitivity of Ascochyta rabiei to azoxystrobin, pyraclostrobin, and boscalid. Plant Disease, 92: 295-300. https://doi.org/10.1094/pdis-92-2-0295

تاريخ الاستلام: 2019/6/19؛ تاريخ الموافقة على النشر: 2020/1/29 